\title{
Mosque-Based Zakat Collection in Maximizing Zakat Potential in Yogyakarta
}

\author{
Syayyidah Maftuhatul Jannah' ${ }^{1}$, Hasan Al-Banna ${ }^{1 *}$ \\ ${ }^{1}$ Faculty of Islamic Economic and Business, UIN Sunan Kalijaga, \\ Yogyakarta, Indonesia \\ *hasan.bana@uin-suka.ac.id
}

\section{Article History}

\begin{tabular}{lll}
\hline Received & $:$ & $2020-03-06$ \\
\hline Revised & $:$ & $2020-12-22$ \\
\hline Accepted & $:$ & $2020-12-22$ \\
\hline
\end{tabular}

Abstract

Introduction to The Problem: Indonesia as the most populous Muslim country has a huge potential for zakat collection. However, the zakat collection never meets its potential. Hence, the need for localization is critical to maximizing the zakat collection.

Objective Study: this paper attempt to develop the mosque-based zakat collection to maximize the potential of zakat.

Methodology: based on the literature review and empirical investigation, the self-administered questionnaire is used to collect the data. Hence, we use the Partial Least Square Structural Equation Modelling (PLS-SEM) to analyze the data. The sample of this research is the mosque management (takmir masjid) in Yogyakarta. A random sampling technique is used to determine the samples. Hence, service quality and zakat distribution are independent variable and intention to distribute the zakat as dependent variable. While trust as variable moderating between dependent and independent variables.

Findings: This study found that the service quality of the zakat institution significantly influences the intention to distribute the zakat. While zakat distribution influences insignificantly the intention to distribute the zakat. Meanwhile, trust moderates between zakat distribution from zakat institution to intention to distribute the zakat.

Paper Type: Research paper

Keywords: intention to distribute the zakat; localization of zakat; mosquebased zakat collection; zakat collection.

Ihtifaz: Journal of Islamic Economics, Finance, and Banking
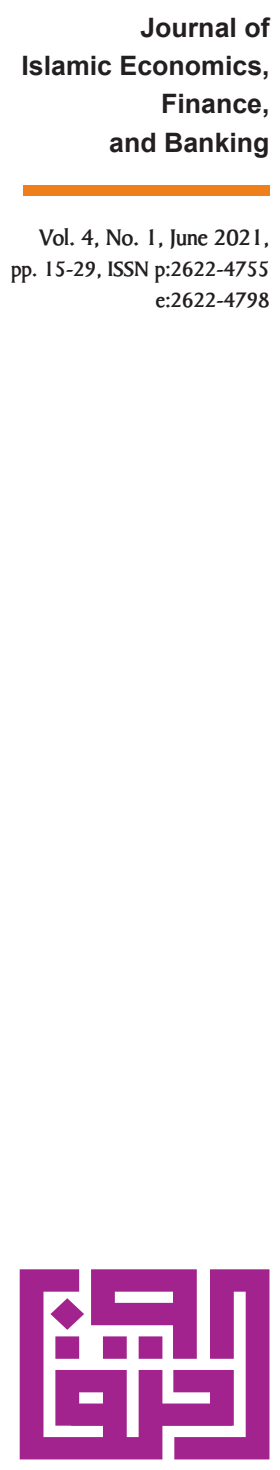

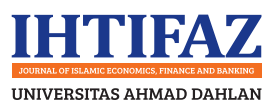

Kampus 4 Universitas Ahmad Dahlan Jl. Ringroad Selatan, Tamanan Yanguntapan, Bantul Yogyakarta 55191

e-mail : ihtifaz@uad.ac.id 


\section{INTRODUCTION}

The development of zakat in Indonesia has significantly increased IHTIFAZ - JIEFB since the governor released the constitution of zakat management in 1999. In 2016, BAZNAS recorded that the total zakat collection reached Rp5.017,29 billion and raised 37.34\% YoY (Outlook Zakat Indonesia, 2018). However, the amount of the zakat collection doesn't meet its true potential. Indonesia as the most populous Muslim country has huge potential in zakat collection. According to BAZNAS, the zakat potential of Indonesia reaches 3.4\% of the national income or 217 billion rupiahs (Outlook Zakat Indonesia, 2018). Relating to this, the zakat collection in Indonesia can grow bigger than before.

Hence, there are obstacles to why zakat collection in Indonesia never reaches true potential. The first, the legal factor, there is a bias in the constitution of zakat management such as unobvious function, supervision, and implementation of zakat collection. Then, it causes a lack of coordination among zakat institutions such as BAZ and LAZ. Hence, the absence of muzaki pressure to pay the zakat under the legal form. Due to the absence of pressure, many of the muzaki don't comply with their obligation. The second, social factor, the lack of understanding of the Muslim community in the obligation of zakat. On the other hand, the religiosity level of the Muslim community still lower level of religiosity. Hence, they couldn't differentiate between zakat, infaq, and shodaqoh due to the lack of understanding of Islamic principles (Johari et al., 2015). The third, institutional factor includes trust in zakat institutions. Although, the society's distrust in the zakat institution causes the distribution of zakat directly from the muzaki to the mustahiq. Since that, zakat collection and distribution is hampered (Sari, 2013).

On the other hand, the mosque as a holy place for the Muslim community has a vital role in the development of Muslim civilization. Hence, in the period of the prophet Muhammad PBUH mosque become not only a worship place but also a place for developing education, counseling, and social activities (Kausar et al., 2016). Nowadays, it is possible to return the function of the mosque as function as the period of Prophet Muhammad PBUH to develop the education, to collect the zakat, and to distribute the zakat (Kausar et al., 2016; Bahari \& Shihabbuddin, 2016). Thus, the mosque has a strong relationship with the Muslim community (Wahid, 2011).

However, the lack of trust in the Muslim community in the zakat institution led them to avoid paying zakat through the zakat institution. They prefer to pay the zakat through the nearest mosque (Daulay et al., n.d.). Thus, the mosque is nearer than the zakat institution for the Muslim community. Hence, the Muslim community fully trusted mosque management (Takmir masjid) rather than zakat institution 
management (Wahid, 2011). Moreover, the Muslim community assumes that the distribution of zakat through mosque is more beneficial to their neighborhood compare to zakat institution (Novianto \& Nafik, 2014). Also, previous studies showed that localization of zakat collection and distribution management is critical (Masyita, 2018; Johari et al., 2015; Aziz et al., 2018; I. N. Hanifah et al., 2020).

Therefore, to tackle the issues of zakat collection and distribution

zakat institutions should build a partnership with the local mosque (i.e localization) to maximize the zakat collection (Kausar et al., 2016). Moreover, mosque as worship place generates income from the infaq and shodaqoh from the Muslim community in their daily worship. Then, mosque management can distribute half of the income of the mosque to the zakat institution. However, this occasion is debatable regarding the lack of trust of the Muslim community including mosque management (takmir masjid) in the zakat institution (Masyita, 2018).

Thus, this paper attempts to analyze the intention of the mosque management to distribute their income to the zakat institution to maximize the zakat collection. We put the distribution of the zakat and service quality as the dependent variable and the intention of the mosque management to distribute the zakat as the independent variable. Hence, we add trust as a moderating variable to moderate between zakat distribution and intention to distribute the zakat.

\section{LITERATURE REVIEW}

\section{Mosque-based zakat collection}

Mosque or masjid refers to the Arabic word sajada mean to prostrate. In the period of the prophet, the mosque is not only the place of prayer and worship but also the place for Muslims to develop education and create social activities (Kausar et al., 2016). Hence, the mosque which identifies as a non-profit organization (NPO) play a significant role in enhancing the Muslim community in term of economic. However, mosque as NPO generates income from the local Muslim community, corporation, government, and other parties such as infaq, shodaqoh, and donations (Salwani et al., 2014). Besides, the number of existing mosques in Indonesia can give advantages to develop Islamic social finance.

On the other hand, the classic problem occurs when the zakat collection in Indonesia never meets the true potential. Due to this, poverty alleviation is hampered. Therefore, the need for localization and integration between the zakat institution and the existing mosque is critical to maximizing the zakat collection (Aziz et al., 2018; Manara, 2018; Wahid, 2011; Hanifah et al., 2020). According to (Masyita, 2018) there are seven advantages of localization of zakat, the first, effective, and efficiency in zakat collection and distribution. The second, involving the local Muslim community create responsibility between the needy 
and the have. The third, local community can assess the performance of the zakat management system. The fourth, minimize the error at the operational level. Fifth, identifying the issues becomes easier. The sixth, create simple and easy coordination. The seventh, building synergy among stakeholders.

The Figure 1 describes the path of localization and integration between the existing mosque and the zakat institution to maximize the zakat fund. The first step, mosque receive the fund from the Muslim community such as zakat, infaq, and shodaqoh. Hence, the fund is assumed as the income of the mosque. Second, the mosque management distributes half of the income to the zakat institution. The third, zakat institution distributes the zakat fund to the asnaf through the programs. Hence, the mosque can be the alternative way to collect the zakat, infaq, and shodaqoh from the local Muslim community. Meanwhile, the fund is collected, mosque management transfers half of the fund to the zakat institution. This occasion led the zakat collection to increase respectively.

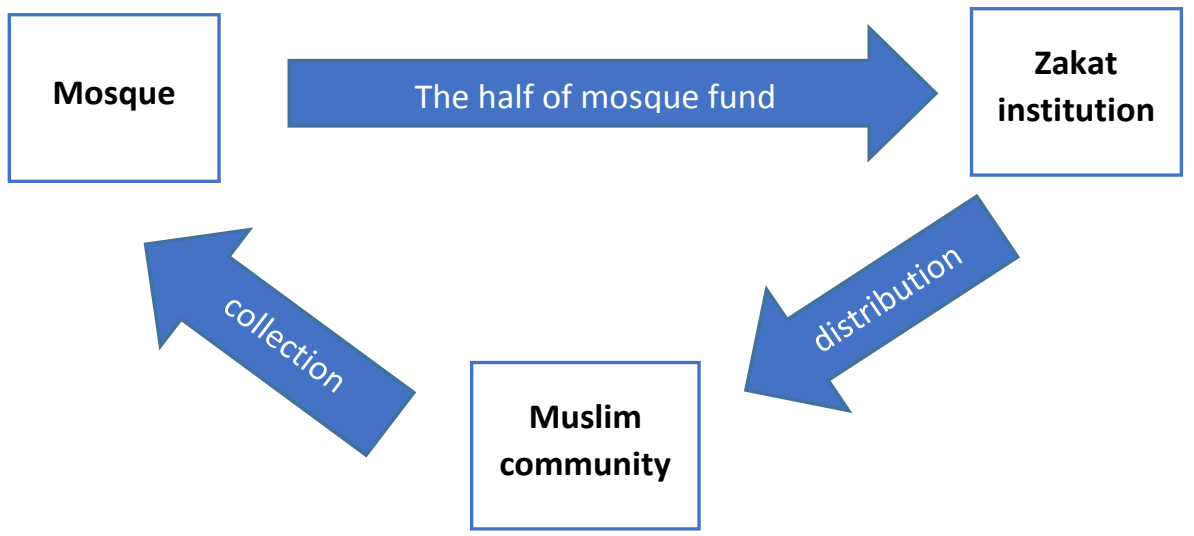

Figure 1. Mosque-based zakat collection

\section{Zakat Distribution}

There are three philosophies of zakat, namely for social, religious, and economic purposes. All these philosophies have the same goal which is to be able to help one another by supporting their wealth (Rahman et al., 2016). Hence, the rich can distribute their wealth with those who are unable to increase their purchasing power who ultimately want to be approved for economic growth. Besides, the distribution of zakat prevents poor people from engaging in illegal activities or just wanting to get their needs (Rahman et al., 2016).

The distribution of zakat differs from other charitable practices or in nonprofit organizations, thus the fund must be distributed to eight groups of asnaf (Ghazali, Saad, \& Abdul Wahab, 2016), such as Fakir (people who do not have assets), Poor (people whose income 
is not sufficient), Riqab (slave), Gharim (a person who has a lot of debt), converts (new converts to Islam), Fisabilillah (fighters in the path of Allah), Ibn Sabil (pilgrims and overseas students), and Amil Zakat (committee for receiving and managing zakat funds). However, although the management of zakat collection can be improved, issues related to the distribution of zakat are still considered unsatisfactory (Ahmad, Othman, \& Salleh, 2015). Moreover, ineffective distribution

Journal of Islamic Economics, Finance, and Banking

Vol. 4, No. 1, June 2021 , pp. 15-29, ISSN p:2622-4755 e:2622-4798 creates dissatisfaction with the zakat payers. In this case, the mosque management (takmir) as zakat distributors, may feel dissatisfied if the zakat institutions, such as BAZNAS, are unable to distribute zakat properly. Previous studies have shown the problem of inefficiency with the distribution of zakat recipients, giving rise to negative perceptions of zakat institutions (Abdullah \& Saad, 2016; Ghazali et al., 2016).

However, to maintain the performance of zakat institutions, satisfaction with the distribution of zakat must be improved (Zainal, Abu Bakar, Al, \& Saad, 2016). If zakat distribution is not handled properly, it harms the development of zakat institutions (Ahmad et al., 2015). The more satisfied with the zakat distribution, the more trust in zakat institutions, and vice versa (Zainal et al., 2016). This is in line with the number of previous studies conducted by Yeh \& Li (2009), where the level of satisfaction is the key determinant in gaining trust. Several studies have confirmed that trust is the result of a progressive generation of customer satisfaction with products or services (Manzano, Pérez, Mafé, \& Blas, 2010; Carranza, Díaz, \& Martín-Consuegra, 2018), which in this case can be associated with satisfaction mosque management (takmir) on the distribution of zakat.

\section{Service Quality}

Customer perceptions of service quality have received wide attention from academic researchers and market practitioners (Yeh \& Li, 2009). In the field of marketing, Parasuraman et al. (1985) in Yeh \& Li (2009) argue that service quality is based on a comparison between what customers feel and what is provided. Woodside et al. (1989) in Che-hui, Jyh-Jeng, Ying-Hueih, \& Chang-Jhan (2001) add that service quality is the overall evaluation of customers on service providers' service processes. Service quality has always been a major factor in measuring performance (Parasuraman et al., 1991 in Che-hui et al., 2001).

Gronroos (1984) in Yap, Ramayah, \& Wan Shahidan (2012) proposed the concept of service quality where service quality consists of two dimensions, namely (1) technical quality which is the quality of what is delivered; (2) functional quality, which is the quality of how services are delivered. Several researchers have developed a scale to measure the service quality in several contexts, considering a combination of tangible and intangible elements (Carranza et al., 2018). Parasuraman et al. (1998) in Yap et al. (2012) propose five dimensions of service 
experience in their famous SERVQUAL model. SERVQUAL measures service quality as five dimensions, namely reliability, responsiveness, IHTIFAZ - JIEFB assurance, empathy, and physical evidence.

Hence, previous studies have shown that measurements of service quality may differ, depending on the type of industry (Moghavvemi, Lee, \& Lee, 2018). In 2003, overall service quality was represented by human skills, tangible variables, and empathy (Jabnoun \& Hassan Al-Tamimi, 2003 in Moghavvemi et al., 2018). However, the concept of service quality has been extended to customer focus, employee service, comfort, empathy, and service architecture (Muhammad Awan, Shahzad Bukhari, \& Iqbal, 2011; Moghavvemi et al., 2018).

Service quality can be defined as the customer's perception of how good the service is (Czepiel, 1990 in Ahmad et al., 2015). Anber Abraheem (2011) in Ahmad et al. (2015) assumed that quality is a significant important matter and becomes an organizational strategic weapon. In the context of customer service, good quality is a package of services including the quality of products, services, and also the environment in which goods or services are provided (Brady \& Cronin, 2014 in Zainal et al., 2016). Service quality leads to the quality of management.

Within the scope of zakat, the satisfaction of zakat payers with the quality of zakat institution services will increase zakat collection (Mohd Noor, Al, \& Saad, 2016). Thus, supported by a study conducted by Sahidi (2013) in Zainal et al. (2016) that the role of zakat institutions in providing quality services is an important factor to attract and encourage business people to pay zakat. Saad et al. (2009) in Zainal et al. (2016) found that by improving service quality, compliance in paying zakat will be better.

Service quality in the field of zakat can be defined as how well the institution of zakat manages its resources and distributes them adequately to Asnaf (the party who deserves zakat) (Wahab \& Rahim Abdul Rahman, 2011; Muhammad \& Saad, 2016). Service quality has been found as an important determinant or determinant of trust. Consumer evaluations of service quality play a significant role in determining their perception of trust in service providers (Chiou \& Droge, 2006 in Che-hui et al., 2001). Good and consistent service quality will create customer trust (Harza et al., 2009; Kantsperger \& Kunz 2010 in Zainal et al., 2016). In this study, the intended customers are the mosque management (takmir). Good quality of service from zakat institutions, such as BAZNAS, will encourage the creation of trust from the mosque management. This is in line with previous research which shows that service quality is felt positively and significantly influences trust (Yeh \& Li, 2009; Doney \& Cannon, 1997 in Yap et al., 2012; Aydin \& Ozer, 2005 in Yap et al., 2012). 


\section{Trust}

Trust is seen as important in the process of building and maintaining relationships, although it is also recognized that it is difficult to manage (Bejou et al., 1998 in Norizan \& Nor Asiah, 2010). According to Aydin and Ozer (2005) in Yap et al. (2012), to gain trust, one party must believe that the other party will take actions that will produce positive results for it and the customer must regard quality as something positive. Therefore, in building trust, customers should not only see positive results but also believe these positive results will continue in the future (Yap et al., 2012). When the level of intimacy between one person and another and transaction security mechanisms are insufficient, trust helps reduce uncertainty (Che-hui et al., 2001).

Trust can be interpreted as an individual's belief in others, which can be influenced by perceptions of integrity, virtue, and competence (McKnight et al., 2002; Lin, 2011 in Akroush \& Al-Debei, 2015). Trust can be described as an expectation that others will not behave opportunistically (Gefen et al., 2003 in Akroush \& Al-Debei, 2015). From a sociological perspective, trust is defined as the dependence of one party on the behavior of another party in carrying out a particular job (Sztompka, 1999 in Ghazali et al., 2016). This interpretation is appropriate to describe the roles and responsibilities of zakat institutions in collecting and distributing zakat for eligible zakat recipients.

In Mohd Noor et al. (2016) stated that trust is a concept that has been studied in various areas, such as information technology services (Min, Dingtao \& Yan, 2015), the banking industry (Fatma, Rahman, \& Khan, 2015), and schools (Gupta \& Kumar, 2015). Trust is also found in some zakat studies, but mostly as an independent variable. In this study, researchers tried to set the trust variable as a mediating variable. Zakat institutions must appear clean because the form of trust in institutions greatly influences the trust of contributors, in this case, the mosque takmir, to continue to contribute and remain committed (Torres-Moraga, Vásquez-Párraga, \& Barra, 2010; Ghazali et al., 2016) with helped distribute zakat.

\section{Conceptual Framework}

This study developed a conceptual framework using several variables, namely (1) zakat distribution and service quality as an independent variable, (2) intention to distribute zakat as the dependent variable, and (3) trust as a moderator variable.

Hence, previous studies on zakat, focus more on the determinant factors of intention to pay zakat. The novelty of this paper is more on the factors that influence mosque management to distribute the zakat (intention to distribute zakat) to existing zakat institutions. Moreover, to increase the ability of mosque management's intention to distribute

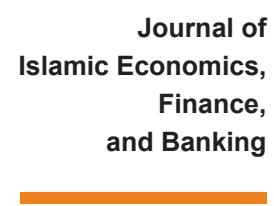

Vol. 4, No. 1, June 2021, pp. 15-29, ISSN p:2622-4755 e:2622-4798 
zakat, several relevant factors need to be considered (Armitage \& Conner, 2001; Rivis \& Sheeran, 2003 in Hasbullah, Friday, Mad, \& Salleh, IHTIFAZ - JIEFB 2014). These factors proposed in this study are the distribution of zakat and service quality. Both factors are assessed based on the mosque management's perception of the existing zakat institutions.

On the other hand, previous studies often put trust as an independent variable. But most studies test trust as an independent variable. However, this paper adds trust as a moderator between the distribution of zakat and the intention to distribute zakat. Thus, trust is at the core of a positive relationship in various contexts (Noor et al., 2016).

The Figure 2 explains the PLS-SEM model in this study. Where we put the service quality and distribution of zakat variables as independent variables and the intention to distribute zakat as the dependent variable. Then we place the trust variable as a moderating variable between the distribution of zakat and the desire to distribute zakat

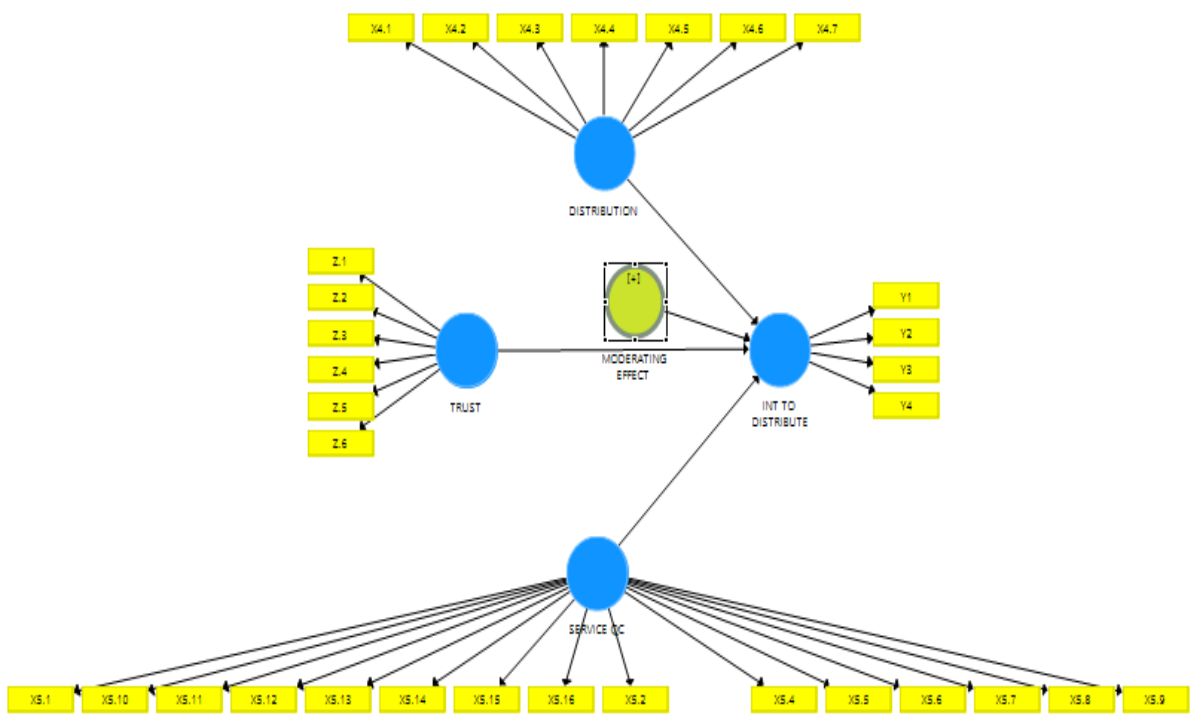

Figure 2. Conceptual framework

\section{METHODOLOGY}

\section{Data}

The population is the number of elements expected to make conclusions (Cooper \& Schindler, 2011). The population in this study is the mosque management (takmir masjid) in several mosques spread in Yogyakarta. Related to sampling, this study uses a simple random sampling technique. This is based on populations that have the same opportunity to be selected as sample members. Hence, a simple random sampling technique is used in this study due to each element of the population being known and has the same opportunity to be 
selected (Cooper \& Schindler, 2011). The sample in this study is the mosque management (takmir masjid) located in Yogyakarta. The total sample of this study were 100 mosque administrators (takmir masjid) in Yogyakarta. In this paper, the type of data collected is primary data, namely by using a self-administered questionnaire. Moreover, the selfadministered questionnaire material contains statements regarding the variables of service quality, zakat distribution, trust, and intention of distributing zakat in mosques. Each answer point on the questionnaire items was determined using a Likert scale from 1 to 4 , where the scale of $1=$ strongly disagree, 2 = disagree, $3=$ agree, and $4=$ strongly agree.

\section{Methodology}

hat has been collected. Hence, the validity test on PLS-SEM uses convergent validity and Average Variance Extracted (AVE) values. The Data is valid if the outer loading value is more than 0.7 and the $A V E$ value is $\geq 0.5$. While the reliability test uses the Cronbach Alpha value, the data is reliable if the Cronbach alpha value and composite reliability are $\geq 0.7$ (Hair, Sarstedt, Hopkins, \& Kuppelwieser, 2014). Then, the data is analyzed through structural modeling conducted on the outer model test. In the $\operatorname{str} R^{2}$. Where the value of $R^{2}$ describes the determinant level of independent variables on the dependent variable. Furthermore, the hypothesis was tested using a t-value (1.98) and a $p$-value (significant at $5 \%$ ). The hypothesis is accepted if the t-value is higher than the t-table (1.98) and the $p$-value is lower or equal to 0.05 (Hair, Ringle, \& Sarstedt, 2011).

\section{RESULT AND DISCUSSION}

\section{Result}

The results of variable statistical tests, validity and reliability tests, model tests, and hypothesis testing have been carried out to answer research problems. Table 1 represents the test results the relationship between variables

Table 1. Correlations among variables

\begin{tabular}{lccccc}
\hline \multicolumn{1}{c}{ Variable } & DZ & KMZ & ME & KL & K \\
\hline Zakat distribution (DZ) & 1.000 & & & & \\
\hline $\begin{array}{l}\text { Intention to distribute } \\
\text { the zakat (IDZ) }\end{array}$ & 0.664 & 1.000 & & & \\
\hline Moderating Effect & -0.302 & -0.373 & 1.000 & & \\
\hline Service quality (SQ) & 0.820 & 0.689 & -0.262 & 1.000 & \\
\hline Trust (T) & 0.666 & 0.524 & -0.150 & 0.757 & 1.000 \\
\hline
\end{tabular}


In PLS-SEM, validity and reliability tests need to be done before testing the hypotheses in the inner model. The validity test in this study uses convergent validity. A variable is declared valid if each statement item has an outer loading value higher than 0.7 and each construct has an AVE (Average Variance Extracted) value of $\geq 0.5$ (Hair, Ringle, et al., 2014). Based on the results in Table 2, it can be concluded that all variables are valid. Thus, the value of outer loading $\geq 0.7$ and the value AVE $\geq 0.5$.

Table 2. Validity test

\begin{tabular}{|c|c|c|}
\hline Variabel & $\begin{array}{c}\text { Factor } \\
\text { Loadings }\end{array}$ & $\begin{array}{c}\text { Average Variance } \\
\text { Extracted (AVE) }\end{array}$ \\
\hline \multicolumn{2}{|c|}{ Zakat Distribution } & \multirow{8}{*}{0.646} \\
\hline$X 4.1$ & 0.828 & \\
\hline$X 4.2$ & 0.776 & \\
\hline$X 4.3$ & 0.834 & \\
\hline$X 4.4$ & 0.864 & \\
\hline$X 4.5$ & 0.850 & \\
\hline$X 4.6$ & 0.729 & \\
\hline$X 4.7$ & 0.731 & \\
\hline \multicolumn{2}{|c|}{ Service Quality } & \multirow{16}{*}{0.719} \\
\hline$\times 5.1$ & 0.714 & \\
\hline$\times 5.10$ & 0.885 & \\
\hline$X 5.11$ & 0.886 & \\
\hline $\mathrm{X} 5.12$ & 0.855 & \\
\hline$\times 5.13$ & 0.901 & \\
\hline$\times 5.14$ & 0.851 & \\
\hline$\times 5.15$ & 0.875 & \\
\hline$\times 5.16$ & 0.867 & \\
\hline$\times 5.2$ & 0.799 & \\
\hline$\times 5.4$ & 0.839 & \\
\hline$\times 5.5$ & 0.848 & \\
\hline$\times 5.6$ & 0.866 & \\
\hline$\times 5.7$ & 0.830 & \\
\hline$\times 5.8$ & 0.849 & \\
\hline$\times 5.9$ & 0.835 & \\
\hline \multicolumn{2}{|c|}{$\begin{array}{c}\text { Desire to Distribute } \\
\text { Zakat }\end{array}$} & \multirow{5}{*}{0.801} \\
\hline Y1 & 0.874 & \\
\hline $\mathrm{Y} 2$ & 0.907 & \\
\hline Y3 & 0.915 & \\
\hline Y4 & 0.883 & \\
\hline
\end{tabular}




\begin{tabular}{|c|c|c|}
\hline Trust & & \multirow{7}{*}{0.695} \\
\hline Z.1 & 0.798 & \\
\hline Z.2 & 0.849 & \\
\hline Z.3 & 0.848 & \\
\hline$Z .4$ & 0.839 & \\
\hline Z.5 & 0.803 & \\
\hline Z.6 & 0.862 & \\
\hline
\end{tabular}

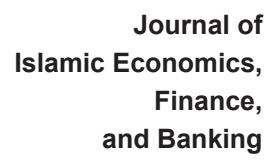

Vol. 4, No. 1, June 2021, pp. 15-29, ISSN p:2622-4755 e:2622-4798

Furthermore, to determine the reliability of a variable is determined by the value of Cronbach's alpha and composite reliability (Hair, Ringle, et al., 2014). A variable is declared reliable if the value of Cronbach's alpha and composite reliability $\geq 0.7$. Based on this, it shows in Table 3 that all variables are reliable.

Table 3. Reliability test

\begin{tabular}{lcc}
\hline \multicolumn{1}{c}{ Variable } & $\begin{array}{c}\text { Cronbach's } \\
\text { Alpha }\end{array}$ & $\begin{array}{c}\text { Composite } \\
\text { Reliability }\end{array}$ \\
\hline Zakat distribution (DZ) & 0.908 & 0.927 \\
\hline Service quality (SQ) & 0.972 & 0.974 \\
\hline $\begin{array}{l}\text { Intention to distribute the } \\
\text { zakat (IDZ) }\end{array}$ & 0.917 & 0.941 \\
\hline Trust (T) & 0.914 & 0.932 \\
\hline
\end{tabular}

In the PLS-SEM model, the quality of the model is not measured using statistical goodness of fit but is based on the ability to predict endogenous constructs (Hair, Ringle, et al., 2014). Among the criteria used in these measurements is the coefficient of determination $\left(R^{2}\right.$ value) which represents the impact of exogenous variables (variable $X$ ) on endogenous variables (variable $Y$ ). Table 4, the value of $R^{2}$ is 0.535 $(53.5 \%)$. This means that the variable Intention to Distribute Zakat (IDZ) is influenced by the Zakat Distribution (ZD) and Service Quality (SQ) variable by $53.5 \%$, while $46.5 \%$ is influenced by other variables outside the model.

Table 4. Measurement of Quality Model Based on $\mathrm{R}^{2}$ Value

\begin{tabular}{ccc}
\hline Variable & $\mathbf{R}^{\mathbf{2}}$ & Adjusted $\mathbf{R}^{\mathbf{2}}$ \\
\hline Intention to distribute (IDZ) & 0.535 & 0.556 \\
\hline
\end{tabular}

Table 5 shows that ZD insignificantly influences IDZ ( $p>0.05)$ with a coefficient value of 0.252 . Hypothesis 1 becomes unsupported. However, the trust variable has moderated the relationship between ZD and IDZ ( $p>0.05$ ) so that hypothesis 3 was supported. Also, SQ was 
found significantly influence the IDZ $(p<0.05)$ with a coefficient value of 0.435 so that hypothesis 2 was supported.

Table 5. Hypothesis Testing

\begin{tabular}{lcl}
\hline Hipotesis & Path Coefficient & $\boldsymbol{p}$-Value \\
\hline DZ > IDZ & 0.252 & $0.093^{* *}$ \\
\hline SQ > IDZ & 0.435 & $0.005^{*}$ \\
\hline Moderating Effect > IDZ & -0.156 & $0.018^{*}$ \\
\hline DZ: Distribution of Zakat; SQ: Service Quality; IDZ: Intention to \\
$\begin{array}{l}\text { Distribute Zakat; T: Trust; } \\
{ }^{*} p<0.05 ; * * p<0.1\end{array}$
\end{tabular}

\section{Analysis}

Based on constitution No. 23 of 2011 concerning Management of Zakat Article 1 paragraph 2, management of zakat is carried out by the Amil Zakat Agency (BAZ) or the Amil Zakat Institution (LAZ). This is also based on Indonesia's zakat potential as the most populous Muslim country. Zakat is not only discussing the obligation of muzakki to pay zakat but also how the responsibility of the amil in zakat collection. Hence, this makes the importance of BAZ and LAZ efforts in the success of zakat fundraising activities. The next concern is how effective the zakat institution is in collecting and distributing zakat (Ardiani, 2019).

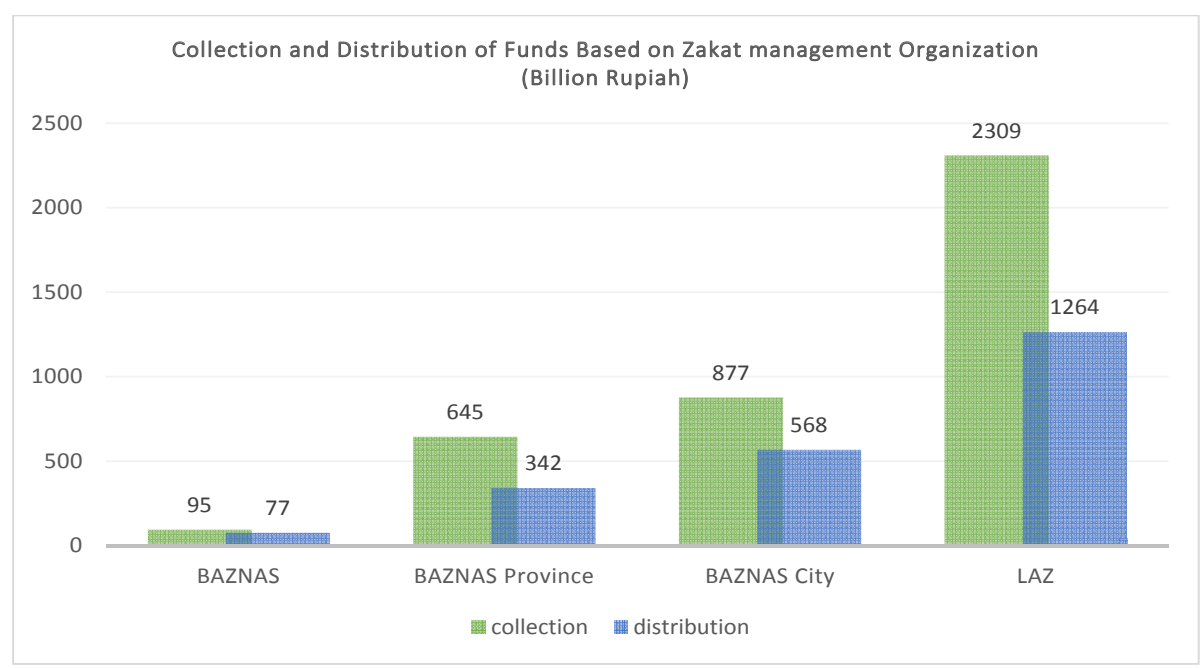

Figure 3. Collection and Distribution of zakat

The effectiveness of zakat management is one indicator of the success of zakat institutions which can be seen from the ratio of the total distribution of zakat to the total collection of zakat (Indonesia Zakat Outlook 2017 1, 2017). According to data from BAZNAS in 2015, the absorption rate of zakat funds (distribution of zakat funds) is still at 
$61.6 \%$. This figure cannot be said to be bad, but it is still in the level of effectiveness of zakat management which is "sufficient" (quite effective).

The data can be linked to the results of hypothesis 1 testing, where the zakat distribution variable by zakat institutions does not significantly influence the desire of mosque management to distribute zakat. That is, the mosque management has doubts about how the zakat institution manages the collected zakat, especially in the distribution of zakat. Starting from the allegation of a complicated system of channeling funds to the lack of openness and transparency that cast doubt on the ineffectiveness of channeling funds was the reason the mosque management were reluctant to channel the collected zakat funds into existing zakat institutions. This seems to justify the statement that the issue related to the distribution of zakat is considered unsatisfactory (Ahmad et al., 2015). Therefore, attention needs to be paid to the zakat agencies to further socialization related to the existing zakat management system. Hence, an effort to increase the trust of the mosque management as the agency that can maximize the potential of zakat in Indonesia through the distribution of zakat funds collected at the mosque to local zakat institutions.

Hence, Trust is a vital element (Noor et al., 2016; Andiani, Hafidhuddin, Beik, \& Ali, 2018) which can be the key to channeling zakat funds through zakat institutions. This empirical investigation states that the trust variable can moderate the relationship between the zakat distribution variables and the zakat institution to the intention of the mosque management to distribute the zakat. Moreover, zakat institutions must be transparent due to the form of trust in institutions strongly influences the trust of donors to continue to contribute (Torres-Moraga et al., 2010; Ghazali, Al, Saad, Syahir, \& Wahab, 2016).

Apart from the distribution of zakat, to increase the trust can be done by looking at the quality of the services of zakat institutions to the community (Hazra \& Srivastava, 2016; Zainal, 2016). The number of literature on zakat, the service quality of zakat institution is indeed considered not much to highlight. Whereas the issue of service quality becomes an important issue in the zakat institution since it is related to how the zakat agency encourages the society to pay zakat (Saad, Wahab, \& Hussain, 2018) then it needs to be evaluated. Kamil (2002) in Muhammad \& Saad (2016) found that the level of service quality of zakat institutions affects the compliance of zakat payers. Thus, there is satisfaction with the services provided. Hypothesis 2 test results also support what was found by previous researchers. The quality of zakat agency services can be said to be good because it can encourage the intention of the mosque management to help distribute zakat funds to local zakat institutions. 


\section{CONCLUSION}

The result found that the service quality of the zakat institution IHTIFAZ - JIEFB significantly influences $(0.05>0.005)$ the intention to distribute the zakat collection from mosque management to the zakat institution. Meanwhile, the zakat distribution programs insignificantly influence $(0.05<0.093)$ the intention to distribute the zakat collection from mosque management to zakat institution. Moreover, trust successfully moderates between the zakat distribution program and the intention to distribute the zakat collection. Hence, this occasion indicates that mosque management is reluctant to distribute half of the mosque's income to the zakat institution due to the lack of trust on the side of mosque management. However, the zakat potential in Indonesia can be increased along with the integration among stakeholders and localization of zakat collection through the existing mosque. Hence, zakat institutions should build a partnership with an existing mosque as the nearest place to the local community. In the other hand, zakat institutions should increase trust in the mosque management and more transparency about the zakat distribution program to the stakeholders.

\section{REFERENCES}

Aziz, M. A., Din, B. H., \& Abdulsomad, K. (2018). The contribution of localization management system on zakat institution performance. International Journal of Supply Chain Management, 7(1), 201-208.

Bahari, C. A. B., \& Shihabbuddin, A. (2016). Exploration of the Role of Mosques in Community Development: Malaysian Experience. 3rd International Conference on Arabic Studies and Islamic Civilization, 2016(March), 36-44.

Daulay, A. H., Lubis, I., \& Soc, M. Analisis Faktor-Faktor Penyebab Keengganan Masyarakat Membayar Zakat Melalui Instansi Bazis/ Laz Di Kota Medan ( Studi Kasus : Masyarakat Kecamatan Medan Tembung ).

Hanifah, I. N., Yuri, A., Wahyudi, R., \& Rifan, A. A. (2020). Analisis Knowledge, Attitude, And Practice (Kap) Terhadap Manajemen Keuangan Masjid Di D.I.Yogyakarta. EcoPlan : Journal of Economics and Development Studies, 3(29), 17-21.

Johari, F., Ali, A. F. M., \& Aziz, M. R. A. (2015). A Review of Literatures on Current Zakat Issues: An Analysis Between 2003-2013. International Review of Research in Emerging Markets and the Global Economy (IRREM), 1(2), 336-363.

Kausar, A., Alauddin, M., \& Rokibul Kabir, M. (2016). A Masjid Based Zakat Management Model in Alleviating Poverty: Bangladesh Perspective. International Journal of Ethics in Social Sciences, 4(2), 2308-5096. 
Manara, A. S. (2018). Strategy Model for Increasing the Potential of Zakat through the Crowdfunding-Zakat System to overcome Poverty in Indonesia. 17-31.

Masyita, D. (2018). Lessons Learned of Zakat Management from Different Era and Countries. Al-Iqtishad: Jurnal Ilmu Ekonomi Syariah, 10(2), 441-456. https://doi.org/10.15408/aiq.v10i2.7237

Novianto, H. R., \& Nafik, M. (2014). Mengapa Masyarakat Memilih Menunaikan Zakat di Masjid Dibandingkan Dengan Lembaga Zakat? (Studi Kasus pada Masyarakat desa Kramat Jegu Kecamatan Taman Kabupaten Sidoarjo) - Why People Prefer to Pay Zakat Through the Mosque? Jurnal Ekonomi Syariah Teori Dan Terapan, 1(3), 221-236. https://doi.org/http://dx.doi.org/10.20473/vol1iss20143pp\%25p

Outlook Zakat Indonesia. (2018). Pusat Kajian Strategis BAZNAS.

Salwani, I., Hidayah, N., Aziz, A., \& Noorman, M. (2014). Mosque fund management : issues on accountability and internal controls. Procedia - Social and Behavioral Sciences, 145, 189-194. https:// doi.org/10.1016/j.sbspro.2014.06.026

Sari, M. D. (2013). Review on Indonesian Zakah Management and Obstacles. Social Sciences, 2(2), 76. https://doi.org/10.11648/j. Ss.20130202.18

Wahid, H. (2011). Localization Of Zakat Distribution And The Role Of Mosque : Perceptions Of Amil And Zakat Recipients In. 1-25. 